\title{
SUPPORT TO YOUNG FARMERS THROUGH AGRICULTURAL POLICY MEASURES - THE EXPERIENCE OF THE EU AND SERBIA
}

Katarina Djuric ${ }^{1}$, Boris Kuzman ${ }^{2}$, Radivoj Prodanovic ${ }^{3}$

${ }^{*}$ Corresponding author E-mail: katarina.djuric@polj.uns.ac.rs

A R T I C L E I N F O
Review Article
Received: 23 October 2018
Accepted: 12 March 2019
doi:10.5937/ekoPolj1901237D
UDC
338.246.027:323.333(4-672 EU)(497.11)

Keywords:

agricultural policy, young farmers, support measures, rural regions

JEL: Q13, Q18, R51

\section{A B S T R A C T}

The purpose of this paper is to analyze agricultural policy measures aimed at young farmers and to compare the support system of the European Union and the Republic of Serbia.

The dominant method in the research is the descriptive analysis. The comparative analysis method is used for investigating advantages and limitations of the support to young farmers in the EU and the Republic of Serbia.

The unfavorable age structure of farmers represents the essential limitation for the sustainable development of agriculture and rural areas. In order to solve this problem, it is necessary to improve and strengthen agricultural policy measures of support to young farmers, which will lead to property increase, diversification of income and higher standards of living and consequently to the decision of young people to stay in the village and work in agriculture.

(C) 2019 EA. All rights reserved.

\section{Introduction}

In 2015 the European Commission proclaimed the support to young farmers as one of the priorities of agricultural policy. The EU Commissioner for agriculture Phil Hogan stressed that "generational renewal is an issue that goes far beyond a reduction in the average age of farmers in the EU. It is also about empowering a new generation of highly-qualified young farmers to bring the full benefits of technology to support sustainable farming practices in Europe (EC, 2017a). Key questions regarding our near future are: who will cultivate the land; how to provide sustainable development of rural regions and why is the number of young farmers decreasing?

1 Katarina Djuric, PhD, Associate Professor, University of Novi Sad, Faculty of Agriculture, Trg Dositeja Obradovića 8, 21000 Novi Sad, Serbia, Phone: + 381 (21) 4853 232, E-mail: katarina.djuric@polj.uns.ac.rs ORCID: 0000-0003-4587-4855

2 Boris Kuzman, $\mathrm{PhD}$, Associate Professor, Institute of Agricultural Economics, Volgina Street no. 15, 11060 Belgrade, Serbia, Phone: +381 63590 129, E-mail: kuzmanboris@yahoo.com ORCID: 0000-0002-8661-2993

3 Radivoj Prodanovic, PhD, Assistant Professor, University Business Academy in Novi Sad, Faculty of Economics and Engineering Management in Novi Sad, Cvecarska Street no. 2, 21000 Novi Sad, Serbia, Phone: +381 21400 484, E-mail: rprodanovic@fimek.edu.rs ORCID: 0000-0002-7088-8506 
Numerous studies have been dealing with issues of unfavorable economic and social changes among rural population (Zagata, 2017; Zagata, Sutherland,2015; Stockdale, 2004; Rovny, 2016 ). Farmers, local stakeholders, policy makers and researchers have been trying to find the reasons and analyze potential implications, primarily, unfavorable demographic trends.

The analysis of agricultural structure in EU countries indicates that due to structural changes, that is, merging smallholdings to large holdings, the number of holdings is decreasing while their average size is increasing (Đurić, 2018). Data gathered from EU countries indicate that a drop in the share of farm managers aged 65 and over is proportional to the increase of the holding size and decrease of their total number. Consequently, countries where smallholdings prevail are significantly affected by a slow generational renewal in agriculture. The impact of the farm size on the farmer age structure is so distinctive that some authors even argue that "the young farmer problem" can be regarded as "the small holding problem" (Zagata, Sutherland, 2015). This problem is particularly emphasized in the countries of Eastern Europe which have major restrictions regarding the approach of young farmers to agricultural land. The Republic of Serbia is one of the countries whose agricultural sector is characterized by unfavourable ownership structure where small scale holdings are more prevalent (Đurić et al, 2016). In addition, major depopulation of rural areas raises doubts about the possibility of generational renewal.

Social and economic restrictions regarding rural area development, caused by unfavourable age structure of farmers, represent a burden to all European countries. For this reason, support measures to young farmers have become one of the priorities, both within rural development and agricultural policy. Incentives to young farmers and young rural population in general are a condition sine qua non for sustainable development of village and agriculture.

The primary aim of this paper is to present support measures of the agricultural policy intended for young rural population, primarily young farmers. Furthermore, the paper compares the system of support to young farmers in the European Union and the Republic of Serbia. The effort has been made to explore the impact of agricultural policy measures on generational renewal in agriculture. The evaluation of effectiveness of agricultural policy support measures for young farmers, which have been applied so far, represents the basis for analyzing the impact of such support, when it comes to the decision of young people to work in agriculture and live in rural areas.

\section{Materials and methods}

The dominant method in the research is the descriptive analysis. The comparative analysis method is used for exploring advantages and limitations of the support to young farmers in the EU and the Republic of Serbia. Also, indicators, logic and other standard scientific methods are used. 
Published scientific papers have been used as a reference for current research and experience related to measures of agricultural and rural development policy aimed at young farmers. The legislation of the European Union together with legislation and development documents of the Republic of Serbia have also been explored. Publications of the Statistical Office of the Republic of Serbia are used in order to gain insight into the demographic structure of rural regions in Serbia.

\section{Young farmers and young rural population in EU countries}

One of the most important dimensions of structural changes in agriculture of the European Union is the aging of farming population (Rovny, 2016). Only $6 \%$ of farmers in the European Union are younger than 35, while more than a half is older than 55 (Happe et al, 2008). Data on age structure of farm managers in EU-28 in the period between 2005 and 2013 show the decrease in the number of managers younger than 35 and increase in the number of farmers aged 54 and over (Table 1).

Table 1. Distribution of farm managers in EU-28 by age

\begin{tabular}{|c|c|c|}
\hline Year & Farmers under 35 years of age & Farmers 54 years and over \\
\hline 2005 & $6.9 \%$ & $54.1 \%$ \\
\hline 2007 & $6.2 \%$ & $55.5 \%$ \\
\hline 2010 & $7.5 \%$ & $53.2 \%$ \\
\hline 2013 & $6.0 \%$ & $55.8 \%$ \\
\hline
\end{tabular}

Source: Matthews, 2018

The question is if a decreasing potential for generational renewal is a problem of European agriculture and agricultural policy. Are longer schooling period and longer longevity reasons which contribute to increasingly unfavourable age structure or there are some other factors involved? (Matthews, 2018).

SWOT analysis of the rural regions within the EU emphasizes that rural areas in the EU meet various development restrictions originating from demographic structure (EC, 2017b).

According to data from 2017, 28\% of the EU-28 population lives in rural areas. There are also considerable differences regarding the share of rural population in certain member countries (from $45 \%$ to $56.2 \%$ in Lithuania, Denmark, Croatia, Latvia, Hungary, Slovenia and Luxemburg and $14.7 \%$ to $22.4 \%$ in Germany, Italy, Belgium, Great Britain and Holland, to only $0.3 \%$ in Malta (Eurostat, 2017).

Rural population dynamics differ in different EU countries and regions. Countries of Central and Eastern European Union are characterized by depopulation of rural areas and concentration of people in larger urban centers. Contrary to this group of countries, there is an increase in population in the so-called peri-urban areas in western part of the EU. These areas are populated by people from urban regions who would like to enjoy the benefits of living in the countryside compared to the life in cities (EC, 2017b). 
The share of female population in rural regions is lower than in peri-urban and urban areas. This trend is particularly visible after 2004 that is, after the admission of countries from Central and Eastern Europe in the European Union (EC, 2017). The decrease in the share of female population in rural areas has a negative effect on the survival and development of rural areas, both in terms of birthrate and in terms of development of some agricultural branches, which traditionally employ women (Bogdanov, 2015).

Rural areas have a large share of population aged 65 and over as compared to the share of the same population living in urban and peri-urban areas. The greatest share of young population (between 15 and 24 years of age) in rural regions is in Estonia, Lithuania, Latvia, Poland, Ireland, the Czech Republic, Romania and Slovakia (Eurostat, 2009). Apart from Ireland, all other countries with the highest share of young people in rural areas are from Eastern Europe, that is, former socialist countries. Specific features of agricultural development and differences in the structure of agricultural holdings in this group of countries in comparison with old member countries (EU-15) also cause differences in the structure of labour force in agricultural sector (Rovny, 2016). As opposed to this group of countries, the lowest share of young people in the total number of rural population is present in France, Italy, Germany, Denmark and Holland (Table 2).

Table 2. The share of young rural population in the total population in EU countries

\begin{tabular}{|l|c|c|c|c|}
\hline & $\begin{array}{c}\text { Predominantly } \\
\text { urban regions }\end{array}$ & $\begin{array}{c}\text { Mixed rural- } \\
\text { urban regions }\end{array}$ & $\begin{array}{c}\text { Predominantly } \\
\text { rural regions }\end{array}$ & All rural regions \\
\cline { 2 - 5 } & \multicolumn{2}{|c|}{ \% proportion of population aged 15 to 24 in the total population } \\
\hline Austria & 10.9 & 11.8 & 11.9 & 11.4 \\
\hline Belgium & 12.1 & 12.0 & 12.5 & 12.2 \\
\hline Bulgaria & 12.4 & 12.9 & 12.5 & 12.7 \\
\hline Czech Republic & 11.6 & 13.0 & 13.5 & 12.8 \\
\hline Germany & 11.4 & 11.4 & 11.6 & 11.4 \\
\hline Denmark & 11.9 & 12.4 & 11.7 & 12.0 \\
\hline Estonia & 14.3 & 14.4 & 16.8 & 14.6 \\
\hline Spain & 10.6 & 11.0 & 11.5 & 10.9 \\
\hline Finland & 12.6 & 12.1 & 12.3 & 12.4 \\
\hline France & 13.9 & 13.0 & 10.9 & 12.9 \\
\hline Greece & 13.6 & 14.2 & 14.1 & 14.0 \\
\hline Hungary & 10.7 & 13.0 & 13.1 & 12.7 \\
\hline Ireland & 16.2 & - & 14.4 & 14.9 \\
\hline Italy & 9.8 & 10.5 & 10.6 & 10.2 \\
\hline Lithuania & 14.3 & 15.9 & 16.9 & 15.7 \\
\hline Latvia & 14.0 & 16.0 & 16.5 & 15.6 \\
\hline Holland & 12.1 & 12.5 & 11.2 & 12.2 \\
\hline Poland & 12.9 & 14.9 & 16.0 & 14.9 \\
\hline Portugal & 11.0 & 11.7 & 10.6 & 11.1 \\
\hline Romania & 13.3 & 14.6 & 14.3 & 14.4 \\
\hline Sweden & 12.3 & 13.4 & 13.5 & 13.2 \\
\hline Slovenia & - & 12.4 & 11.6 & 12.0 \\
\hline Slovakia & 13.0 & 15.5 & 14.5 & 15.0 \\
\hline Great Britain & 12.3 & 11.8 & 12.5 & 12.1 \\
\hline
\end{tabular}

Source: Eurostat, 2009 
One of the crucial challenges of sustainable development of rural communities within the European Union is the exodus of young people (Shucksmith, 2010). Stockdale (2004) believes that it is not the out-migration of young people which is responsible for the survival of rural areas, but the in-migration, that is a small number of people who come to live in rural areas. Namely, he thinks that the main reason for rural outmigration is education of young people. Young and educated people find jobs in cities and do not return to rural areas they came from.

Parents who are farmer managers usually encourage their children and provide them higher education so that they get the opportunity to work outside agriculture and away from rural areas, thus eventually enabling them higher standards of living. This behavior pattern is stated by many authors who studied young rural population problems. For example, Kasimis et al (2010) write about situation in Greece: "Rural regions in Greece face the problem of rejection by the younger generation of badly paid jobs in agriculture. Improvements in the level of education and the standard of living as well as the spread of urban consumption patterns in the past three decades have led to the creation of high expectations in the younger generation. This led to migration from rural areas and from agriculture."

Comprehensive survey was carried out in EU countries as part of the project "Policies and Young People in Rural Areas" in 1999 and 2000. It deals with young population and their attitude regarding the life in rural areas. Advantages and restrictions of living in rural areas expressed by young people from the EU are shown in Table 3.

Table 3. Positive and negative characteristics of rural areas

\begin{tabular}{|c|c|}
\hline Positive characteristics & Negative characteristics \\
\hline Rural landscapes, natural environment & Difficult access, remoteness \\
\hline Calm, peacefulness, security & Lack of social activities, isolation \\
\hline Existence of attractive towns nearby & No public transport \\
\hline Good housing conditions & Ageing population \\
\hline Many job opportunities & Restricted job market \\
\hline Large offer of sport activities & Lack of activities for young women \\
\hline
\end{tabular}

Source: Schucksmith, 2010

The level of development of physical and institutional infrastructure and availability of public services, situation on the local job market, level of development of social networks and the role of family represent key aspects which determine the perception of young people of rural areas and their survival. Young rural population is worried about economic and social survival of their local communities and insist on higher level of participation in decision making process, creation of rural development policy and programme and their implementation. 


\section{Demographic characteristics of rural regions in Serbia}

The 2011 Census of the Republic of Serbia recorded a significant population decline, especially in rural areas of the country. The negative birthrate, rural out-migration to cities and abroad resulted in a drop of rural population in Serbia of below three million (Table 4).

Table 4. Changes in the population number according to the type of settlement

\begin{tabular}{|l|c|c|c|}
\hline & 2002 census & 2011 census & 2011/2002 index \\
\hline Total & $7,498,001$ & $7,189,862$ & 95.9 \\
\hline Urban settlements & $4,225,896$ & $4,271,872$ & 101.1 \\
\hline Other settlements & $3,272,105$ & $2,914,990$ & 89.1 \\
\hline Rural population in total (in \%) & 43.6 & 40.6 & \\
\hline
\end{tabular}

Source: OG RS, 2014

Observed at the regional level, the depopulation process and demographic exodus of villages is mostly present in the least developed regions of southern and eastern Serbia, which saw a decline of as much as $19 \%$ in the nine year period (OG RS, 85/2014). Gender differences are also increasing. Data from 2011 census confirm that the decrease in number of residents is higher with female than with male population, both in urban and rural regions. Such unfavourable aging and gender structure represents one of the key restrictions of structural reform in agriculture. It also results in the growth of hidden unemployment on agricultural holdings.

Potentials of human capital, that is, labour force in agriculture of the Republic of Serbia, can be best observed by monitoring the change in number of certain age groups (Table 5).

Table 5. Age structure according to the type of settlement

\begin{tabular}{|l|c|c|c|c|}
\hline \multirow{2}{*}{ Age structure } & \multicolumn{2}{|c|}{$\begin{array}{c}\text { Share of individual age groups in the } \\
\text { total population (in \%), 2011 }\end{array}$} & \multicolumn{2}{c|}{$\begin{array}{c}\text { Changes in the population in 2011 } \\
\text { compared to 2002 }\end{array}$} \\
\cline { 2 - 5 } & Urban regions & Other regions & Urban regions & Other regions \\
\hline $0-14$ & 14.5 & 13.9 & -6.0 & -21.6 \\
\hline $15-29$ & 19.0 & 17.6 & -10.3 & -16.1 \\
\hline $30-49$ & 28.3 & 25.2 & -2.8 & -15.7 \\
\hline $50-64$ & 22.7 & 23.2 & 20.0 & 13.3 \\
\hline $65+$ & 15.6 & 20.1 & 12.7 & -10.0 \\
\hline TOTAL & 100 & 100 & 100 & 100 \\
\hline
\end{tabular}

Source: OG RS, 2014

The share of future (0-14 years) and potential labour force (15-29 years) in total population in rural regions is $31.5 \%$ (33.5\% in urban regions), which is lower compared to the share of population ceasing active employment (50-64 years and over 65), whose share accounts for $43.3 \%$ (38.3\% in urban regions). This kind of population structure, observed according to age groups and their working potential, questions the possibility of generational renewal in the agriculture of our country, particularly in rural areas. 
Even more unfavorable demographic picture is obtained if observed by a trend change of population according to certain age groups. Compared to the previous census, the population decline was most significant in the category of working population and in the group which presents a potential labor force. Also, higher negative change rate of people living in rural areas as compared to urban areas, visible in all population categories up to the age of 49, are an indicator of the necessity to introduce a set of measures which will prevent further and more drastic out-migration of young working people from villages, and hence from agriculture.

\section{EU support for young farmers}

In general, the system of agricultural policy support makes it more difficult for new entrants to farming. CAP support pushes up land prices and thus adds to the time required for new entrants who are not inheriting to put together the necessary capital (Matthews, 2013).

Ex-post analysis of LEADER+ program pointed to certain drawbacks in terms of participation of young farmers in the decision making process. In addition, it has been estimated that the role of local action groups (LAG) was overemphasized in the process of implementation of development project and that LAGs are the ones who restrict direct participation of young rural population in projects aimed at them (Đurić, Njegovan, 2015).

In order to efficiently support young farmers through a subsidy system it is necessary to understand their problems (Zagata, 2017). It was necessary to develop CAP measures and directed funds exclusively to the category of young farmers. These measures are essential for providing their successful economic and social integration. Young people, who wish to engage in agriculture, abandon the traditional way of production and in the effort to modernize production they have certain demands for information, education, retraining and institutional support.

A set of measures of support to young farmers was introduced in the 2007-2013 programming period within CAP Pillar 2, with a dominant M 112 Setting-up of young farmers, targeting directly young farmers (Reg. 1698/2005). Almost 200000 young farmers received EU aid for setting up in the 2007-2013 period (ECA, 2017). Potential users of funds granted under M 112 have to meet the following conditions:

- be up to 40 years of age and set up an agricultural holding for the first time,

- have adequate occupational skills and competence;

- submit a business plan for the development of their farming activities.

Indirectly, young farmers were also supported under the following Pillar II measures:

- Vocational training and information actions (M 111),

- Use of advisory services (M 114), 
- Modernisation of agricultural holdings (M 121),

- Rural infrastructure (M 125).

Early retirement schemes, introduced as far back as in 1960, have not contributed as expected to the intergenerational transfer in agriculture of European Union. Therefore, the implementation of this scheme has been abandoned in the present programme (Zagata, Sutherland, 2015; Davis et al, 2013).

In the current 2014-2020 period, M 112 Setting-up of young farmers is followed by corresponding measure M 06 Farm and business development measure (sub-measure 6.1 - Business start-up aid for young farmers). This measure is implemented in 92 out of the 118 Rural Development Programmes (RDPs) across 24 out of the 28 EU Member States (ECA, 2017).

Furthermore, under the CAP Pillar 2 in the 2014-2020 period, the support to young farmers has been provided in the form of following measures (Reg. 1305/2013):

- Knowledge transfer and information actions (M 01),

- Advisory services, farm management and farm relief services (M 02),

- Investments in physical assets (M 04),

- Cooperation, drawing up a business plan (M 16).

Income support to young farmers was introduced under the Pillar 1 by Payment for young farmers (a top-up payment of $25 \%$ of the direct payment). Users of funds are young farmers commencing their agricultural activity who are no more than 40 years of age in the year of the first submission of the application under the basic payment scheme or under the single area payment scheme (Reg. 1307/2013).

The total EU budget allocated specifically for the support to young farmers 20072020 is 9.6 billion euro. It doubled from 3.2 billion euro in 2007-2013 provided under the Pillar 2 setting-up measure to 6.4 billion euro in 2014-2020, mainly due to the introduction of an additional direct payment to young farmers under Pillar 1. Total public expenditure, including national co-financing of Pillar 2 setting-up measure, is 18.3 billion euro. Nevertheless, the European Court of Auditors (ECA) found that this aid is based on a poorly-defined intervention logic, with no expected result and impact specified and that it should be better targeted to foster effective generational renewal (ECA, 2017).

\section{Support measures to young farmers in the Republic of Serbia}

Agriculture and Rural Development Strategy 2014-2024 (OG RS, 85/2014) provides strategic directions for rural and agricultural development in the Republic of Serbia for the 2014-2020 period. In addition to other development priorities, the Strategy stipulates that the welfare of rural population should be improved in order to stop negative demographic trends. In addition, special attention is given to the unfavourable 
situation of women and youth on rural job market. The job market analysis has shown that it is the category of young people in rural regions which is to a high level excluded from this market and faced with inability to find jobs. Young people aged between 15 and 24 are employed in non-agricultural sectors only in $21 \%$ cases.

The development program of AP Vojvodina 2014-2020 (OG APV, 13/2014) defines four priority axes: 1 . Development of human resources, 2 . Development of infrastructure and conditions for decent life and work, 3. Sustainable economic growth, 4. Development of institutional infrastructure.

The second priority axis contains a measure which deals with the improvement of quality of life in order to increase employment and stop depopulation. Better connectivity among institutions, improvement of utility and information infrastructure, as well as more public and private investments in rural areas should be recognized as an initial incentive for provision of better living and working conditions in rural areas. More emphasis is laid on the position of marginal groups - women and youth and therefore on the need to organize their formal and informal education and reinforce their empowerment in the field of self-employment and entrepreneurship.

Implementation of support to young farmers in Serbia, both on the national and provincial level, started in 2017. Users of this support are young farmers aged 18 to 40 . The provision of incentives aimed at young farmers in terms of "start-up" programme has been realized through grants for development and improvement of agricultural production and agricultural production and processing.

Incentives for diversification of income and improvement of quality of life in rural areas through support to young farmers have been envisaged in the Republic of Serbia (Official Gazette RS 45/2018 and 50/2018). The purpose of these incentives is to support investments for the development and improvement of primary plant and animal production, as well as for the purchase of breeding farm animals for agricultural holdings of young farmers. The beneficiaries of these incentives can be farm holders and/or members of commercial family farms if the farm is registered in the Farm Register for the first time and if the applicant is between 18 and 40 years of age.

When ranking applicants who applied for financial support, priority is given to:

- Investments intended for the production of veal and beef, lamb and kid, followed by vegetables, flowers, fruit, grapes, aromatic and medicinal herbs;

- $\quad$ Female applicants;

- Applicants with the degree in agriculture, veterinary medicine and/or food processing technology;

Applicants who are the residents of underdeveloped municipalities;

- $\quad$ Applicants who are employed only in agriculture;

- $\quad$ Large families. 
Table 6. Criteria for granting subsidies to young farmers in rural regions of AP Vojvodina

\begin{tabular}{|l|l|c|}
\hline Criteria & Scoring mode & Points \\
\hline \multirow{4}{*}{ Age of applicant } & From 18 to 25 & 25 \\
\cline { 2 - 3 } & From 25 to 35 & 20 \\
\cline { 2 - 3 } & From 35 to 40 & 15 \\
\hline Applicant is a woman & Yes/No & $10 / 0$ \\
\hline Agricultural holding is in a less-favoured region & Yes/No & $10 / 0$ \\
\hline \multirow{5}{*}{ Applicant has appropriate expert knowledge } & $\begin{array}{l}\text { At least three years of experience in } \\
\text { production - registered in the Farm } \\
\text { Register }\end{array}$ & 5 \\
\cline { 2 - 3 } & High school & 10 \\
\cline { 2 - 3 } & Faculty & $10 / 20 / 40$ \\
\hline Evaluation of sustainability of the investment & Low/medium/high & $\mathbf{1 0 0}$ \\
\hline
\end{tabular}

Source: Provincial Secretariat for Agriculture, Water Management and Forestry, 2018 Potential users of this support at provincial level are obliged, in addition to other stipulated criteria, to submit a business plan as an evidence of the economic sustainability of their project. A part of the grant in the amount of $75 \%$ is paid in advance, whereas the outstanding $25 \%$ of the funds is paid once the investment has been realized. Criteria for allocating grants to young farmers at provincial level are presented in Table 6.

In addition to funds from republic and provincial agricultural budget, young farmers can apply for self-employment subsidies which are realized in cooperation with the National Recruitment Agency. The Development Agency of Serbia also has resources for encouraging women and youth entrepreneurship in rural regions (Jovanović, 2016).

\section{Conclusions}

The share of young rural population in total population as well as the share of young farmers in the total number of agricultural producers is constantly decreasing both in EU countries and in the Republic of Serbia. Unfavourable age structure of farmers is the crucial limitation of the sustainable development of agriculture and rural regions.

The analysis of experience of EU countries shows that the decision of young people to stay on the farm and engage in agriculture depends on numerous factors. Firstly, the size and economic stability of the holding affects the decision of new generations to take over the holding and work in agriculture. Another important factor is the degree of diversification of rural economy. High degree of diversification of the rural economy and engaging in non-agricultural activities provides higher standards of living and positively affects the decision of young people to stay in the village. Rural infrastructure and services also enable more secure future to young people.

Generational renewal in agriculture is supported through implementation of appropriate agricultural policy measures. The European Union has set the support to young farmers as one of the CAP priorities. According to the European Court of Auditors (ECA), this support needs to be better targeted to foster effective generational renewal. Since 2017, 
the Republic of Serbia has started implementing measures for giving incentives to young population to work in agriculture and their effects are yet to be evaluated.

\section{Acknowledgements}

Paper is a part of research within the project no. 114-451-2601/2016-2 "The analysis of production and economic results of business entities in the field of agriculture and food industry of AP Vojvodina", financed by the Provincial Secretariat for Higher Education and Scientific Research of the AP Vojvodina.

\section{Conflict of interests}

The authors declare no conflict of interest.

\section{References}

1. Bogdanov, N. (2015). Rural Development and Rural Policy. Faculty of Agriculture, University of Belgrade. [in Serbian: Богданов, Н. (2015). „Рурални развој и рурална политика", Пољопривредни факултет, Универзитет у Београду].

2. Council Regulation (EC) No. 1698/2005 on support for rural development by the European Agricultural Fund for Rural Development (EAFRD).

3. Davis, J., Caskie, P., \& Wallace, M. (2013). Promoting structural adjustment in agriculture: The economics of New Entrant Schemes for farmers. Food Policy, 40, 90-96.

4. Đurić, K. (2018). Agriculture and rural development of the Republic of Serbia in the process of European integration. Faculty of Agriculture, University of Novi Sad. [in Serbian: Ђурић, К. (2018). Пољопривреда и рурални развој Републике Србије у процесу европских интеграција. Пољопривредни факултет, Универзитет у Новом Саду].

5. Đurić, K., Milović, S., Hyba, H., Prodanović, R., \& Bošković, J. (2016). Comparative Analysis of Agricultural Farms Property Structure in the Republic of Serbia and EU. Economics Theory and Practice, 9 (2), 19-32. [in Serbian: Ђурић, К., Миловић, С., Hyba, Н., Продановић, Р., Бошковић, Ј. (2016). Компаративна анализа поседовне структуре пољопривредних газдинстава у Републици Србији и ЕУ].

6. Đurić, K., \& Njegovan, Z. (2015). Mechanisms of support for young rural population in the European Union, Economics of agriculture, 62 (4), 1003-1016.

7. European Commission (2017a). Generational Renewal through Rural Development. Speech by Commissioner Phil Hogan at JOINT ENRD/CEJA Workshop - $25^{\text {th }}$ January 2017, Brussels, Retrieved from

8. https://ec.europa.eu/commission/commissioners/20142019/hogan/announcements/ speech-commissioner-phil-hogan-joint-enrdceja-workshop-25th-january-2017brussels en (Mart, 02 2019) 
9. European Commission (2017b). Modernizing and Simplifying the CAP. SocioEconomic challenges facing EU agriculture and rural areas. Background Document. Retrieved from

10. https://ec.europa.eu/agriculture/sites/agriculture/files/consultations/capmodernising/soc background final en.pdf (Mart, 02 2019)

11. European Court of Auditors (ECA). (2017). EU support to young farmers should be better targeted to foster effective generational renewal. Special Report No 10/2017, Retrieved from https://www.eca.europa.eu/Lists/ECADocuments/SR17 10/SR YOUNG FARMERS EN.pdf (Mart, 02 2019)

12. Eurostat regional yearbook (EUROSTAT), Retrieved from http://ec.europa.eu/ regional_policy/en/newsroom/news/2017/09/14-09-2017-eurostat-regionalyearbook-2017 (September 08, 2018)

13. European Statistics (EUROSTAT), Statistics on rural areas in the EU, Retrieved from https://ec.europa.eu/eurostat/statisticsexplained/index.php/Statistics_on rural areas in the EU $($ September 08, 2018)

14. Happe, K., Balmann, A., Kellerman, K., \& Sahrbacher, C. (2008). Does structure matter? The impact of switching the agricultural policy regime on farm structures. Journal of Economic Behavior and Organization, 67 (2), 431-444.

15. Jovanović, O. (2016). Institutional support to the development of entrepreneurship in agriculture during structural changes in Serbia, In: Directions of structural change in the process of accession to the European Union (Eds. Minović. J., Stošić, I., Bodroža, D., Drašković, B.), Institute of Economic Sciences, Belgrade, 393-404. [in Serbian: Јовановић, О. (2016). Институционална подршка развоју предузетништва пољопривреде током структурних промена у Србији].

16. Kasimis, C., Papadopoulos, A., \& Pappas, C. (2010). Gaining from Rural Migrants: Migrant Employment Strategies and Socioeconomic Implications for Rural Labour Markets. Sociologia Ruralis, 50 (3), 258-276.

17. Matthews, A. (2013). Wasting money on young farmers? Retrieved from http:// capreform.eu/wasting-money-on-young-farmers/ (September 08, 2018)

18. Matthews, A. (2018). Is there a particular generational renewal problem in EU agriculture, Retrieved from http://capreform.eu/is-there-a-particular-generationalrenewal-problem-in-eu-agriculture/ (September 05, 2018)

19. Ministry of Agriculture, Forestry and Water Management - MAFWM. (2018). For the measure of supporting young farmers three times more money in 2018 [in Serbian: За меру подршке младим пољопривредницима три пута више новца у 2018. години], Retrieved from http://www.minpolj.gov.rs/za-meru-podrske-mladimpoljoprivrednicima-tri-puta-vise-novca-u-2018-godini/ (September 08, 2018) 
20. Official Gazette of the Republic of Serbia - OG RS, no 85/2014. Agriculture and Rural Development Strategy 2014-2024 [in Serbian: Службени гласник Републике Србије, бр. 85/14. Стратегија пољопривреде и руралног развоја Републике Србије за период 2014-2024. године].

21. Official Gazette of the Republic of Serbia - OG RS, no 45/2018 and no 50/2018. Incentives for diversification of income and improvement of quality of life in rural areas through support to young farmers (in Serbian: Службени гласник Републике Србије, бр. 45/2018 и бр.50/2018. Правилник о подстицајима за диверзификацију дохотка и унапређење квалитета живота у руралним подручјима кроз подршку младим пољопривредницима).

22. Official Gazette of the Autonomous Province of Vojvodina - OG APV no 24/2018. Rulebook on allocation of funds for support to young people in rural areas on the territory of AP Vojvodina in 2018 [in Serbian: Службени лист АПВ, бр. 24/2018. Правилник о додели средстава за подршку младима у руралним подручјима на територији АП Војводине у 2018. години].

23. Official Gazette of the Autonomous Province of Vojvodina - OG APV no 13/2014. Development program of AP Vojvodina 2014-2020 [in Serbian: Службени лист АПВ, бр. 13/2014. Програм развоја АП Војводине 2014-2020].

24. Regulation (EU) No. 1305/2013 of the European Parliament and of the Council on support for rural development by the European Agricultural Fund for Rural Development (EAFRD) and repealing Council Regulation No. 1698/2005.

25. Regulation (EU) No. 1307/2013 of the European Parliament and of the Council establishing rules for direct payments to farmers under support schemes within the framework of the CAP and repealing Council Regulation (EC) No. 637/2008 and Council Regulation (EC) No. 73/2009.

26. Rovny, P. (2016). The analysis of farm population with respect to young farmers in the European Union. Procedia - Social and Behavioral Sciences, 220, 391-398.

27. Shucksmith, M. (2010). How to promote the role of youth in rural areas of Europe. Directorate General for internal policies, Policy Department for Structural and Cohesion policies, Retrieved from http:/www.europarl.europa.eu/RegData/etudes/ note/join/2010/438620/IPOL-AGRI NT(2010)438620 EN.pdf (July10, 2018)

28. Stockdale,A. (2004). Rural Out-Migration: Community Consequences and Individual Migrant Experience. Sociologia Ruralis, 44 (2), 167-194.

29. Zagata, L. (2017). Young farmers - Policy implementation after the 2013 CAP reform. Presentation for the Committee on Agriculture and Rural Development, Retrieved from http://www.europarl.europa.eu/cmsdata/133190/Study_Lukas\%20 Zagata-Policy\%20implementation_13-11-2017.pdf (July10, 2018)

30. Zagata, L., \& Sutherland, L.A. (2015). Deconstructing the ,young farmer problem in Europe ": Towards a research agenda. Journal of Rural Studies, 38, 39-51. 